Revista Brasileira de Farmacognosia Brazilian Journal of Pharmacognosy 22(1): 102-108, Jan./Feb. 2012

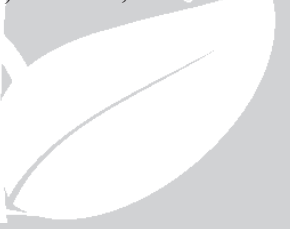

Article

Received 2 Feb 2011

Accepted 25 Apr 2011

Available online 30 Sep 2011

Keywords:

acute and chronic toxicity biochemical parameters

haematologic parameters

histology

Syzygium cumini

ISSN 0102-695X

http://dx.doi.org/10.1590/S0102-

695X2011005000181

\section{The toxicity evaluation of Syzygium cumini leaves in rodents}

\author{
Selma do N. Silva, ${ }^{* 1}$ Iracelle C. Abreu, ${ }^{1}$ Graciela Fernanda \\ C. Silva, ${ }^{1}$ Rachel M. Ribeiro, ${ }^{1}$ Adelson de S. Lopes, ${ }^{2}$ Maria do \\ Socorro de S. Cartágenes, ${ }^{1}$ Sônia Maria de F. Freire, ${ }^{1}$ Antônio \\ Carlos R. Borges, ${ }^{I}$ Marilene Oliveira da R. Borges ${ }^{1}$
}

\author{
${ }^{1}$ Laboratório de Pesquisa e Pós-graduação em Farmacologia, Departamento de \\ Ciências Fisiológicas, Universidade Federal do Maranhão, Brazil, \\ ${ }^{2}$ Laboratório de Histologia, Departamento de Morfologia, Universidade Federal do \\ Maranhão, Brazil.
}

\begin{abstract}
This study aimed to evaluate the safety of the hydroalcoholic extract (HE) of Syzygium cumini (L.) Skeels, Myrtaceae, leaves in rodents. Acute toxicity was evaluated through the determination of a LD50 in mice and rats (up to 14 days). In mice, the oral administration (p.o.) of the HE $(0.1$ at $6 \mathrm{~g} / \mathrm{kg})$ did not cause any death. When administered by intraperitoneal route (i.p.) the $\mathrm{HE}(0.1$ at $1 \mathrm{~g} / \mathrm{kg})$ caused death of the animals (LD50 of $0.489 \mathrm{~g} / \mathrm{kg}$ ). In rats, the HE $(0.5,1$ and $2 \mathrm{~g} / \mathrm{kg}$, p.o.) did not cause any death, while by i.p., only the $2 \mathrm{~g} / \mathrm{kg}$ dose was lethal to $67 \%$ of the animals. To evaluate chronic toxicity, groups of rats daily received the HE $(0.05,0.1$ and $0.25 \mathrm{~g} / \mathrm{kg})$ through p.o., during 30,90 or 180 days and the effects on behavior, body weight, feed consumed were measured. Histology, hematology and biochemical parameters were measured at the end of the treatment. After a 30-day treatment, the HE caused changes in some biochemical parameters. Histological examination of the liver, kidneys, lungs, heart, stomach, intestine and pancreas showed normal architecture suggesting no morphological disturbances. These data may mean that the HE of $S$. cumini does not exert acute or chronic toxic effects by oral administration.
\end{abstract}

\section{Introduction}

Syzygium cumini (L.) Skeels (syn. Syzygium jambos Alston; Eugenia jambos L.; Jambosa jambos Millsp.; Jambosa vulgaris DC.; Caryophyllus jambos Stokes), Myrtaceae, popularly known as "jambolão", is a plant originated from India, acclimatized in Brazil and spread over the entire Brazilian coast. It is widely used by people to treat hemorrhoids, diarrhea, inflammation and diabetes (Lainetti \& Brito, 1979; Pio Corrêa, 1974). It is also often used by local people in state of MaranhãoBrazil to reduce the blood pressure.

From the methanolic extract of the S. cumini leaves two glycoflavonoids have been isolated: myricetin and quercetin (3-O- $\beta$-D-xilopyranosyl (1-2) $\alpha$-Lrhamnopyranosides, which present anti-inflammatory activity (Slowing et al., 1994a; Slowing et al., 1994b). The phytochemical analysis of the aqueous extract of the bark of "jambolão", carried out by colorimetric and chromatographic reactions, suggests a proportion of $70 \%$ of hydrolyzed and condensed tannins, and a small quantity of saponins (Djipa et al., 2000).

It has been shown that the hydroalcoholic extract preparated from the bark of the $S$. cumini has an anti-inflammatory effect, when compared to the effect of acetyl-salicylic acid. This effect was related to the high contents of tannins in the extract, which would probably be responsible for the inhibition of the biosynthesis of prostaglandins (Muruganandan et al., 2001). The ethanolic extract of the S. cumini seeds has a hypoglycemic effect in diabetic rabbits, reducing the level of glucose and of the glycohemoglobin, and increasing the plasma levels of insulin (Sharma et al., 2003). This extract also presents a hypolipidemic effect, reducing the activity of the liver enzyme 3-hydroxy-3-methylglutaryl CoA reductase (HMG-CoA) liver enzyme and therefore reducing the levels of cholesterol and triacylglycerides in the serum. It was recently shown that the methanol and EtOAc extract of $S$. cumini presents a fungicidal activity (Braga et al., 2007; Kuiate et al., 2007). Recent studies also showed that $S$. cumini leaves extracts possessed hypoglycemic activity in addition to a hypolipidemic action in diabetic animals (Schoenfelde et al., 2010). Other investigations suggest that Eugenia jambolana fruit have potential beneficial effects against breast cancer, exhibiting pro- 
apoptotic effects against the MCF-7aro and the MDAMB-231 breast cancer cells, but not towards the normal MCF-10A breast cells (Li et al., 2009).

Although many pharmacologic effects of Syzygium cumini have already been investigated and confirmed, no study has been carried out to confirm the safety of the use of this plant. Thus, the objective of this work was to evaluate the acute and chronic toxicity of the hydroalcoholic extract from S. cumini, taking into consideration that this kind of plant is widely used as medicinal.

\section{Material and Methods}

\section{Animals}

Swiss mice from the species Mus musculus and Wistar rats from the species Rattus norvegicus were used in the experiments. The animals were adults, from both sexes, obtained from Bioterious of Universidade Federal do Maranhão, and were kept under standard conditions of temperature $\left(22 \pm 2{ }^{\circ} \mathrm{C}\right)$ and $12 \mathrm{~h} \mathrm{light} /$ dark cycle, with water and animal feed (Labina, Purina, Co) ad libitum, during the whole period of the experiment. The protocol for these experiments was approved by the Animal Ethics Committee of the Universidade Estadual do Maranhão under approval number 015/2005.

\section{Plant material}

Leaves of jambolão were collected from area at UFMA (Campus Bacanga), São Luís, Maranhao State, Brazil in May 2002. This material was identified as Syzygium cumini (L.) Skeels, Myrtaceae, and a voucher specimen (No 1069) was deposited in the Atico Seabra Herbarium, UFMA. The leaves were dried at room temperature $\left(28-30^{\circ} \mathrm{C}\right)$ and pulverized.

\section{Extract preparation}

The dried powder was macerated in $70 \%$ ethanol at room temperature in a proportion of $1: 3(\mathrm{v} / \mathrm{v})$ with mechanical stirring, on a daily basis. The extract was concentrated in a rotaevaporator under reduced pressure and at a temperature below $60{ }^{\circ} \mathrm{C}$. The hydroalcoholic extract (HE) was obtained from this process, bottled in an amber flask and kept under refrigeration at $4{ }^{\circ} \mathrm{C}$. The dry weight of the resultant crude extract was $210 \mathrm{mg} / \mathrm{mL}$ and the yield was $13.7 \%$. In order to administer the product to animals in the experiments, solutions of the extract were prepared with $0.9 \%$ of $\mathrm{NaCl}$ solution.

\section{Acute toxicity study of extract}

The S. cumini HE was administered to mice and rats by oral (p.o.) and intraperitoneal (i.p.) routes, in an increasing and single dose, in order to determine the lethal dose of $50 \%$ (LD50). The mice were separated in groups of ten animals each (five male and five female) and the animals received the HE by gavage at a dose of 0.1 at $6 \mathrm{~g} / \mathrm{kg}$, while the control group received only a saline solution $(\mathrm{NaCl} 0.9 \% ; 0.1 \mathrm{~mL} / 10 \mathrm{~g})$. The extract was also administered i.p. at doses of $0.1 ; 0.25 ; 0.5$ or $1 \mathrm{~g} / \mathrm{kg}$ in mice. The rats were separated in groups of ten animals each (five male and five female) and the HE was administered p.o. and i.p. route at doses of $0.5 ; 1$ or $2 \mathrm{~g} /$ $\mathrm{kg}$. The signs of toxicity (Malone, 1977) and death were observed up to 14 days after the treatment. The LD50 was calculated by means of the Trimmed SpearmanKarber Method software, version 1.5 (Hamilton et al., 1977). At the end of the period of observation all animals were subjected to an autopsy, in order to perform a macroscopic evaluation of liver, lungs, kidneys, stomach, intestine, heart and pancreas (Larini, 1997; Oga, 2003; Anvisa, 2004).

\section{Chronic toxicity of extract}

Rats were divided at random into a control and experimental groups with ten animals in each group (five male and five female animals). The experimental groups received the Syzygium cumini HE by p.o., at doses of $0.05,0.1$ or $0.25 \mathrm{~g} / \mathrm{kg}$ for 30,90 or 180 days on a daily basis, in order to evaluate the chronic toxicity (Souza Brito, 1994). The animals of control group received a saline solution $(\mathrm{NaCl} 0.9 \% ; 0.1 \mathrm{~mL} / 10 \mathrm{~g})$. Animals were monitored weekly for body weight and food consumption, and daily for behavioral and clinical signs. After 30, 90 or 180 days of exposure, the blood was collected directly from the abdominal aortic under anesthesia (ketamine, $90 \mathrm{mg} / \mathrm{kg}$ and xylazine, $10 \mathrm{mg} / \mathrm{kg}$, i.p.) for haematology and biochemical analysis. Blood samples were collected in tubes with or without EDTA. The anticoagulated blood (EDTA) was analized immediately for haematologial parameters. The second tube was centrifuged at $3000 \mathrm{x}$ $\mathrm{g}$ for $10 \mathrm{~min}$ to obtain the serum, which was stored at $-20{ }^{\circ} \mathrm{C}$ until analysis for biochemical parameters. The biochemical determinations, like total protein (PT), albumin (Alb), amino-transferase aspartate (AST), amino-transferase alanine (ALT), alkaline phosphatase (ALP), glucose (Gl), urea (UR), creatinine (Cr), $\mathrm{Ca}^{2+}$ (calcium), HDL (High-density lipoprotein), TC (total cholesterol) and TG (triacylglycerides), were performed through a spectrophotometer by using standard kits from Labtest ${ }^{\circledR}$. The haematologic parameters like the red blood cell (RBC), hemoglobin $(\mathrm{Hb})$, hematocrit $(\mathrm{Ht})$, mean cell volume (MCV), mean corpuscular hemoglobin $(\mathrm{MCH})$, mean corpuscular hemoglobin concentration (MCHC), white blood cell (WBC) were determined using automatic hematological analyzer (Cell Dyn 1700, Abbott). 


\section{Histological studies}

After collecting blood samples, rats were euthanized by exsanguinations. All animals were subjected to a full and detailed gross necropsy. Histological studies of the liver, kidneys, lungs, heart, stomach, intestine and pancreas were conducted in control and rats treated with hydroalcoholic extract of Syzygium cumini leaves at dose of $0.05,0.1$ and $0.25 \mathrm{~g} / \mathrm{kg}$ for 180 days. Theses organs were carefully dissected out and tissues were cut and fixed in $10 \%$ formalin and the sections stained with haematoxylin and eosin were studied under light microscope (Luna, 1968).

\section{Statistical analysis}

Results are expressed as mean \pm SEM. Significance differences between control and experimental groups were assessed by ANOVA test, followed by the Newman Keuls test, supported by the GraphPad Prism, Inc software, version 5.00 (GraphPad Software Inc., San Diego, CA, USA) at a significance level of $p \leq 0.05$.

\section{Results and Discussion}

When administered orally to rats and mice, at doses up to 2 and $6 \mathrm{~g} / \mathrm{kg}$, respectively, Syzygium cumini HE did not present any sign of acute toxicity or death up to the $14^{\text {th }}$ day of observation, even at doses above $5 \mathrm{~g} /$ $\mathrm{kg}$, which is considered in the existing literature to be the maximum tolerated (Larini, 1997; Oga, 2003; Souza Brito, 1994). Previous pharmacological studies with various parts of the plant have confirmed the therapeutic actions of "jambolão" based on the oral administration of effective doses of $0.2 \mathrm{~g} / \mathrm{kg}$ in rats (Grover et al., 2002; Mukherjee et al., 1998), which led to the conclusion that the active components present in the extract do not promote acute toxicity when orally administered, even when using doses 10 times higher than the effective therapeutic ones, according demonstrate in this work.

The intraperitoneal route, although not used in humans, was selected to determine the inherent toxicity of extract, since the effects of an oral dose are subject to systemic bioavailability and hepatic extraction. In this work, signs of toxicity in accordance with (Malone, 1977) and mortality were observed after the i.p. administration of the extract in mice, causing death in $70 \%$ of the animals at a dose of $0.5 \mathrm{~g} / \mathrm{kg}$, and $100 \%$ when using a dose of 1 $\mathrm{g} / \mathrm{kg}$ (LD50 $0.489 \mathrm{~g} / \mathrm{kg}$ ). When administered i.p. at the highest dose $(2 \mathrm{~g} / \mathrm{kg})$, the extract caused $67 \%$ death in rats, and this procedure did not allow the determination of the LD50 (Larini, 1997). Higher doses were not administered in the peritoneal space due to the increase in the viscosity of the solution, which impaired its manipulation. The effects observed in mice and rats when treated via i.p. were limited to sedation and an increase in the respiratory frequency that occurred just after the HE administration. In the experiment designed to investigate the toxicity after a prolonged exposure to cumulative doses of Syzygium cumini $\mathrm{HE}$ orally at doses of $0.05,0.1$ and $0.25 \mathrm{~g} / \mathrm{kg}$, a variation in the body weight was determined, as well as in the consumption of animal feed, the hematologic and biochemical parameters and the macroscopic and microscopic observation after autopsy in animals treated daily over a period of 30,90 and 180 days (chronic toxicity). The oral and cumulative administration of HE over a long period did not result in any behavioral changes, according to the criteria established by Malone (1997), and did not cause death of the animals.

Changes in the body weigth have been used to assess the course of the disease and the response to therapy of drugs. It was found that the HE administration at doses of $0.05,0.1$ and $0.25 \mathrm{~g} / \mathrm{kg}$ did not interfere with weight gain (Figure 1) in the rats nor in the feed consumption (Figure 3 ) of the animals for 90 days. No significant difference in body weight gain was noted between the control and the treated groups with 0.05 and $0.1 \mathrm{~g} / \mathrm{kg}$ at 180 days of treatment. However, the male rats group dealt with the highest dose $(0.25 \mathrm{~g} / \mathrm{kg})$ of $S$. cumini did not have gain of body weight from $15^{\text {th }}$ week until the end of the treatment (Figure 2a). It was observed that the $\mathrm{HE}$ administration in doses of $0.05,0.1$ and $0.25 \mathrm{~g} / \mathrm{kg}$ did not interfere in the food consumption of animals (Figure 4 ) in this period. Decrease of weight gain may be due to interference caused by the jambolão extract in food absorption.
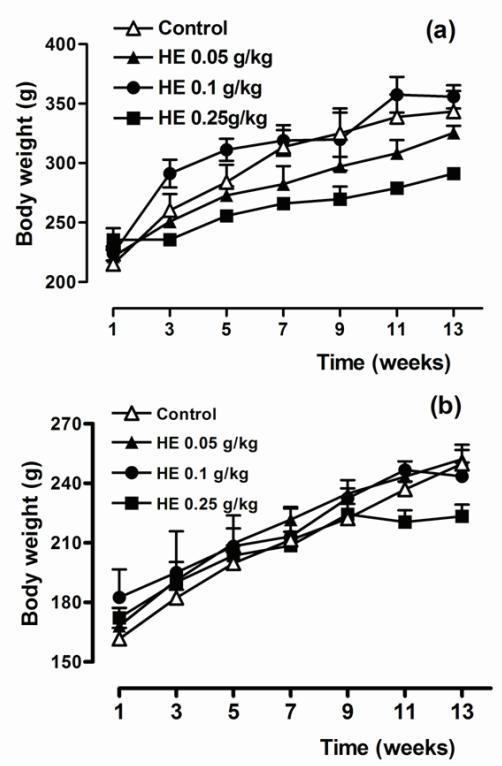

Figure 1. Effect of the chronic administration of Syzygium cumini hydroalcoholic extract (HE) on the rats' body weight $(a=$ male; $b=$ female), considering a daily treatment, during 90 days. Symbols and vertical lines indicate means \pm SEM, respectively ( $\mathrm{n}=10 ; 5 \hat{O}$ and 5 \% $)$. 

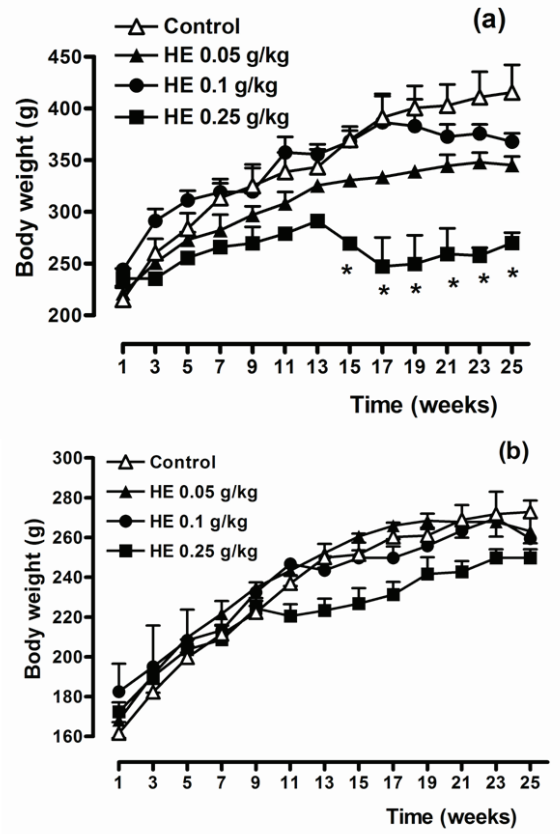

Figure 2. Effect of the chronic administration of Syzygium cumini hydroalcoholic extract (HE) on the body weight of rats $(\mathrm{a}=$ male; $\mathrm{b}=$ female), considering a daily treatment, during 180 days. Symbols and vertical lines indicate means \pm SEM, respectively $(\mathrm{n}=10 ; 5 \hat{\delta}$ and $5 q)$. Values are statistically significant at $* p<0.05$ (ANOVA, Newman Keuls test).

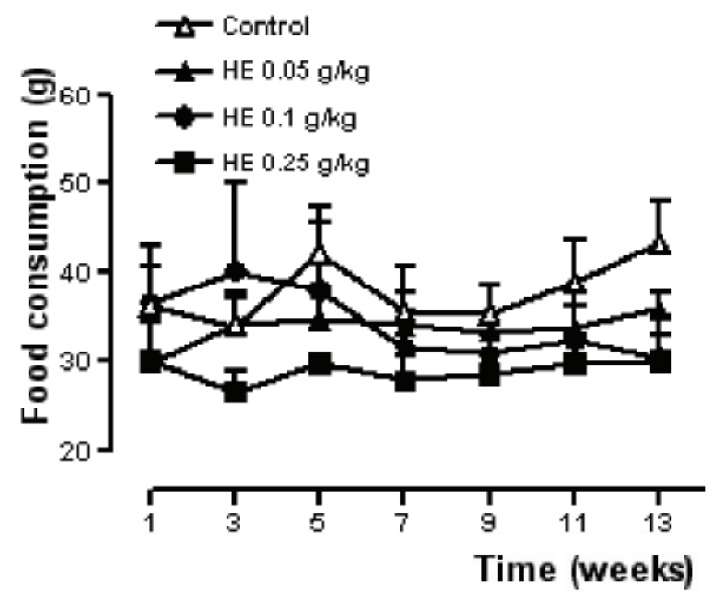

Figure 3. Effect of the chronic administration of Syzygium cumini hydroalcoholic extract (HE) on the food consumption of rats, considering a daily treatment during 90 days. Symbols and vertical lines indicate means \pm SEM, respectively $(\mathrm{n}=10 ; 5 \hat{0}$ and 5ㅇ).

Several biochemical parameters in the blood of the animals which were treated with Syzygium cumini HE were also examined. The biochemical parameters are important because they allow the evaluation of all organs and the general status of the animal's body, especially with regard to renal and liver functions.
The seric levels of urea from the animals treated with $\mathrm{HE}$ at doses of $0.05,0.1$ and $0.25 \mathrm{~g} / \mathrm{kg}$ were reduced by $19.4,13.8$ and $18.4 \%$, respectively, after 30 days, while creatinine showed a reduction of $15.4 \%$ with a dose of $0.25 \mathrm{~g} / \mathrm{kg}$, when compared to the control group (Table 1). Alteration of urea and creatinine in this period is not related with the increase of the used dose and was not reproducible in groups treated with HE over a longer period, which suggesting a transitory alteration of these parameters.

Regarding the investigation of biochemical elements that are markers of hepatocytes or derived from hepatic metabolism provides valuable data for the evaluation of hepatic function. To perform this evaluation, the most widely used laboratory tests are the dosage of plasma concentration of bilirubin, transaminase, alkaline phosphatase, gamma-glutamyl-transferase, total proteins, albumin, prothrombin, ammonia, and biliary acid. Regarding the investigation of hepatic function, in this work the only change observed was an increase in the seric levels of alkaline phosphatase, at the higher dose in the 30-day treatment, which occurred of isolated form and was not followed by any alteration in the value of the transaminase in any of the groups treated.

With reference to the glycemia, the studies that were performed with seeds, fruit and bark of Syzygium cumini, following several different experimental patterns, demonstrated the hypoglycemic and anti-hyperglycemic effects (Achrekar et al., 1991; Ravi et al., 2004; Sharma et al., 2003; Sridhar et al., 2005; Villasenor \& Lamadrid, 2006). Nevertheless, investigations carried out in Brazil have shown that the leaves and the fruits of Syzygium cumini did not have effect on diabetes (Pepato et al., 2005; Teixeira et al., 1990; Teixeira et al., 1997; Teixeira et al., 2000). In this work there was no change in the seric concentration of glucose in animals treated for 30, 90 and 180 days with the Syzygium cumini HE (Tables 1, 2 and 3).

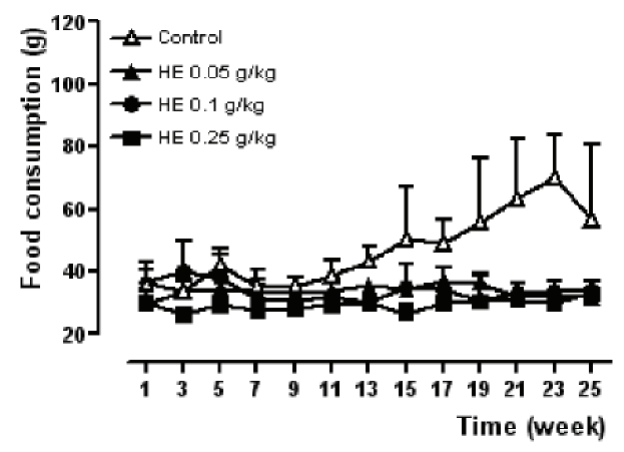

Figure 4. Effect of the chronic administration of Syzygium cumini hydroalcoholic extract (HE) on the food consumption of rats, considering a daily treatment during 180 days. Symbols and vertical lines indicate means \pm SEM, respectively ( $\mathrm{n}=10 ; 5 \hat{\circ}$ and 5 \%). 
Table 1. Biochemical parameters on rats treated with the Syzygium cumini hydroalcoholic extract (HE) for 30 days.

\begin{tabular}{lcccc}
\hline \multirow{2}{*}{ Biochemical parameters } & \multicolumn{3}{c}{ Groups } \\
\cline { 2 - 5 } GL mg/dL & Control & HE $0.05 \mathrm{~g} / \mathrm{kg}$ & HE 0.1 g/kg & HE $0.25 \mathrm{~g} / \mathrm{kg}$ \\
Ur mg/dL & $169.1 \pm 12.31$ & $172.8 \pm 11,52$ & $197.0 \pm 11,19$ & $171.9 \pm 12.81$ \\
Cr mg/dL & $50.25 \pm 2.30$ & $40.5 \pm 2.32^{*}$ & $43.30 \pm 1.19^{*}$ & $41.0 \pm 2.83^{*}$ \\
PT g/dL & $0.65 \pm 0.02$ & $0.61 \pm 0.01$ & $0.70 \pm 0.03$ & $0.55 \pm 0.02^{*}$ \\
ALB g/dL & $5.56 \pm 0.08$ & $5.31 \pm 0.05$ & $5.34 \pm 0.07$ & $5.60 \pm 0.25$ \\
ALP U/L & $2.90 \pm 0.05$ & $2.70 \pm 0.07$ & $2.84 \pm 0.09$ & $2.73 \pm 0.08$ \\
AST U/L & $129.6 \pm 7.86$ & $141.5 \pm 4.42$ & $136.6 \pm 9.37$ & $168.7 \pm 12.77^{*}$ \\
ALT U/L & $108.1 \pm 12.21$ & $99.17 \pm 12.40$ & $88.86 \pm 6.97$ & $72.29 \pm 5.35$ \\
\hline
\end{tabular}

Values in the table are means $\pm \operatorname{SEM}\left(\mathrm{n}=10 ; 5 \hat{\jmath}\right.$ and 5 + ). Values are statistically significant at ${ }^{*} p<0.05$ (ANOVA, Newman Keuls test).

Table 2. Biochemical parameters on rats treated with the Syzygium cumini hydroalcoholic extract (HE) for 90 days.

\begin{tabular}{lcccc}
\hline \multirow{2}{*}{ Biochemical parameters } & \multicolumn{3}{c}{ Groups } \\
\cline { 2 - 5 } GL mg/dL & Control & HE $0.05 \mathrm{~g} / \mathrm{kg}$ & HE 0.1 g/kg & HE $0.25 \mathrm{~g} / \mathrm{kg}$ \\
Ur mg/dL & $133.5 \pm 20.03$ & $145.5 \pm 20.67$ & $120.9 \pm 32.01$ & $127.5 \pm 42.66$ \\
Cr mg/dL & $56.75 \pm 3.81$ & $48.0 \pm 2.75$ & $55.14 \pm 1.80$ & $57.0 \pm 1.27$ \\
PT g/dL & $0.57 \pm 0.04$ & $0.51 \pm 0.04$ & $0.62 \pm 0.06$ & $0.64 \pm 0.04$ \\
ALB g/dL & $6.45 \pm 0.13$ & $6.48 \pm 0.10$ & $6.71 \pm 0.08$ & $6.43 \pm 0.21$ \\
ALP U/L & $2.83 \pm 0.10$ & $2.80 \pm 0.08$ & $2.71 \pm 0.09$ & $2.80 \pm 0.12$ \\
AST U/L & $167.8 \pm 12.35$ & $203.5 \pm 14.29$ & $218.6 \pm 16.74$ & $193.7 \pm 20.40$ \\
ALT U/L & $115.6 \pm 15.40$ & $107.90 \pm 16.40$ & $126.0 \pm 34.22$ & $127.7 \pm 24.74$ \\
\hline
\end{tabular}

Values in the table are means \pm SEM $(\mathrm{n}=10 ; 5 \hat{\delta}$ and 5 \% $)$.

Table 3. Biochemical parameters on rats treated with the Syzigium cumini hydroalcoholic extract (HE) on for 180 days.

\begin{tabular}{lcccc}
\hline \multirow{2}{*}{ Biochemical parameters } & \multicolumn{3}{c}{ Groups } \\
\cline { 2 - 5 } GL mg/dL & Control & HE $0.05 \mathrm{~g} / \mathrm{kg}$ & HE 0.1 g/kg & HE $0.25 \mathrm{~g} / \mathrm{kg}$ \\
\hline Ur mg/dL & $106.0 \pm 3.78$ & $92.57 \pm 6.23$ & $109.4 \pm 3.22$ & $100.4 \pm 4.55$ \\
Cr mg/dL & $67.71 \pm 6.70$ & $69.0 \pm 5.35$ & $65.13 \pm 2.57$ & $66.0 \pm 5.61$ \\
PT g/dL & $0.48 \pm 0.04$ & $0.51 \pm 0.04$ & $0.45 \pm 0.03$ & $0.54 \pm 0.07$ \\
ALB g/dL & $7.61 \pm 0.26$ & $7.97 \pm 0.34$ & $8.37 \pm 0.21$ & $8.34 \pm 0.27$ \\
ALP U/L & $1.17 \pm 0.03$ & $1.09 \pm 0,35$ & $1.09 \pm 0.06$ & $1.22 \pm 0.03$ \\
AST U/L & $84.71 \pm 10.78$ & $112.0 \pm 13.40$ & $128.0 \pm 17.42$ & $135.7 \pm 16.29$ \\
ALT U/L & $123.9 \pm 1.78$ & $141.1 \pm 19.37$ & $116.1 \pm 6.94$ & $132.1 \pm 13.31$ \\
Ca2+ mg/dL & $57.86 \pm 4.93$ & $57.14 \pm 4.86$ & $67.63 \pm 8.16$ & $64.71 \pm 7.17$ \\
HDL mg/dL & $13.17 \pm 0.16$ & $13.17 \pm 0.15$ & $13.40 \pm 0.22$ & $13.34 \pm 0.28$ \\
TC mg/dL & $41.29 \pm 2.33$ & $33.52 \pm 1.54^{*}$ & $38.38 \pm 1.62$ & $34.14 \pm 2.22^{*}$ \\
TG mg/dL & $103.3 \pm 6.41$ & $86.86 \pm 4.30$ & $87.75 \pm 3.51$ & $83.71 \pm 8.96^{*}$
\end{tabular}

Values in the table are means $\pm \operatorname{SEM}(\mathrm{n}=10 ; 5$ and 5 \% $)$. Values are statistically significant at $* p<0.05$ (ANOVA, Newman Keuls test).

In rats treated for 180 days, no differences in the serum levels of ALP, ALT, AST, BUN, total protein, albumin, creatinine, glucose and $\mathrm{Ca}^{2+}$ was found between extract-treated groups and the control groups. It was found that the levels of HDL, triacylglyceride and cholesterol of extract-treated groups were significantly lower than the control group. The seric levels of HDL from the animals that were treated with $\mathrm{HE}$ at doses of 0.05 and $0.25 \mathrm{~g} / \mathrm{kg}$ for 180 days were reduced by 18.8 and $17.3 \%$, respectively, while with a dose of $0.25 \mathrm{~g} / \mathrm{kg}$ cholesterol showed a 
Table 4. Haematologic parameters on rats treated with the Syzygium cumini hydroalcoholic extract (HE) for 180 days.

\begin{tabular}{|c|c|c|c|c|}
\hline \multirow{2}{*}{$\begin{array}{c}\text { Haematologic } \\
\text { parameters }\end{array}$} & \multicolumn{4}{|c|}{ Groups } \\
\hline & Control & $\mathrm{HE} 0.05 \mathrm{~g} / \mathrm{kg}$ & $\mathrm{HE} 0.1 \mathrm{~g} / \mathrm{kg}$ & $\mathrm{HE} 0.25 \mathrm{~g} / \mathrm{kg}$ \\
\hline Erythrocyte $\left(\mathrm{x} 10^{6}\right.$ cells $\left./ \mathrm{mm}^{3}\right)$ & $7.80 \pm 0.22$ & $8.13 \pm 0.16$ & $7.98 \pm 0.26$ & $8.19 \pm 0.17$ \\
\hline $\mathrm{Hb}(\mathrm{g} / \mathrm{dL})$ & $14.34 \pm 0.22$ & $14.35 \pm 0.19$ & $14.30 \pm 0.26$ & $14.44 \pm 0.36$ \\
\hline Ht $(\%)$ & $39.79 \pm 0.97$ & $39.60 \pm 0.50$ & $39.88 \pm 1.16$ & $39.74 \pm 1.31$ \\
\hline $\operatorname{MCV}(f l)$ & $51.00 \pm 0.57$ & $48.75 \pm 0.45$ & $50.00 \pm 0.32$ & $48.43 \pm 0.81$ \\
\hline $\mathrm{MCH}(\mathrm{pg})$ & $18.41 \pm 0.31$ & $17.66 \pm 0.18$ & $17.99 \pm 0.28$ & $17.61 \pm 0.25$ \\
\hline $\mathrm{MCHC} \mathrm{g} / \mathrm{dL}$ & $36.10 \pm 0.53$ & $36.25 \pm 0.16$ & $35.95 \pm 0.45$ & $36.40 \pm 0.40$ \\
\hline WBC $\left(\times 10^{3}\right.$ cells $\left./ \mathrm{mm}^{3}\right)$ & $6.83 \pm 1.14$ & $6.02 \pm 0.72$ & $5.54 \pm 0.63$ & $5.58 \pm 0.66$ \\
\hline $\mathrm{Neu}$ & $0.447 \pm 0.091$ & $0.675 \pm 0.086$ & $0.568 \pm 0.068$ & $0.519 \pm 0.65$ \\
\hline Lyn & $6.023 \pm 1.04$ & $5.208 \pm 0.63$ & $4.795 \pm 0.53$ & $4.843 \pm 0.53$ \\
\hline Mono & $0.119 \pm 0.17$ & $0.104 \pm 0.28$ & $0.119 \pm 0.43$ & $0.090 \pm 0.16$ \\
\hline Eos & $0.058 \pm 0.014$ & $0.047 \pm 0.023$ & $0.044 \pm 0.021$ & $0.031 \pm 0.014$ \\
\hline
\end{tabular}

Values in the table are means \pm SEM $(\mathrm{n}=10 ; 5$ ô and 5 ) .

reduction of $18.9 \%$ when compared to the control group (Table 3). The seric levels of triacylglyceride from the rats that were treated with $\mathrm{HE}$ at all doses were reduced by $45.4,49.6$ and $51.47 \%$, respectively. It is interesting to note that, as stated by Somova et al. (2003), the ursolic and oleanolic acid obtained from the Syzygium presented diuretic activity, reduces two times more than the seric levels of tryglycerides, total cholesterol and lipoprotein fractions.

The hematologic parameters are important ally of the studies toxicity, therefore the hematopoietic system is extremely sensible the activities of toxic agents, mainly those with mutagenic or cytotoxic potential, resulting in qualitative or quantitative alterations, transitory or permanent and that they can limit the use of medicines. With reference to the hematologic parameters evaluated, the group treated with HE for 180 days did not show any alteration treatment-related effects when compared to the control group (Table 4).

To confirm the lack of toxicity of Syzygium cumini, a histologic study was carried out. Microscopic examination of the selected organs (liver, lungs, kidneys, stomach, intestine, heart and pancreas) did not reveal any treatment-related effects showing that the observed elevations in some biochemical parameters might actually be artefactual in nature (data not shown).

This study found evidence to suggest that, based on the interpretation of the analyzed parameters, the hydroalcoholic extract of Syzygium cumini does not produce acute toxic and/or chronic effect when administered orally, but does present acute toxicity when administered via intraperitoneal route.

\section{Acknowledgment}

The authors acknowledge the financial support of CNPq, CAPES and Banco do Nordeste.

\section{References}

Achrekar S, Kaklij GS, Pote MS, Kelkar SM 1991. Hypoglycemic activity of Eugenia jambolana and Ficus bengalensis: mechanism of action. In Vivo 5: 143-147.

Braga FG, Bouzada MLM, Fabri RL, Matos M de O, Moreira FO, Scio E, Coimbra ES 2007. Antileishmanial and antifungal activity of plants used in traditional medicine in Brazil. J Ethnopharmacol 111: 396-402.

Anvisa 2004. Resolução RE nº. 90, de 16 de março. Guia para a realização de estudos de toxicidade pré-clínica de fitoterápicos. Ministério da Saúde, Agência Nacional de Vigilância Sanitária.

Djipa CD, Delmee M, Quetin-Leclercq J 2000. Antimicrobial activity of bark extracts of Syzygium jambos (L.) alston (Myrtaceae). J Ethnopharmacol 71: 307-313.

Grover JK, Yadav S, Vats V 2002. Medicinal plants of India with anti-diabetic potential. J Ethnopharmacol 81: 81100.

Hamilton MA, Russo RC, Thurston RV 1977. Trimmed Sperman-Karber method for estimating median lethal concentration in toxicity bioassays. Environ Sci Technol 11: 714-719.

Kuiate JR, Mouokeu S, Wabo HK, Tane P 2007. Antidermatophytic triterpenoids from Syzygium jambos (L.) Alston (Myrtaceae). Phytother Res 21: 149-152.

Lainetti R, Brito NS 1979. A cura pelas ervas e plantas medicinais brasileiras. Rio de Janeiro: Ediouro.

Larini L 1997. Avaliação toxicológica. In Larini L (ed.) Toxicologia. 3 ed. São Paulo: Manole, p.43-58.

Li L, Adams LS, Chen S, Killian C, Ahmed A, Seeram NP 2009. Eugenia jambolana Lam. Berry extract inhibits growth and induces apoptosis of human breast cancer but not non-tumorigenic breast cells. J Agr Food Chem 
57: $826-831$.

Luna LG 1968. Manual of histologic staining methods of the Armed Forces Institute of Pathology. New York: McGraw Hill.

Malone MH 1977. Pharmacological approaches to natural products screening and evaluation. In Wagner $\mathrm{H}$, Wolf P (eds.) Natural products and plant drugs with pharmacological, biological or therapeutical activity. Berlin: Springer-Verlag, p. 23-53.

Mukherjee PK, Saha K, Murugesan T, Mandal SC, Pal M, Saha BP 1998. Screening of anti-diarrhoeal profile of some plant extracts of a specific region of West Bengal, India. J Ethnopharmacol 60: 85-89.

Muruganandan S, Srinivasan K, Chandra S, Tandan SK, Lal J, Raviprakash V 2001. Anti-inflammatory activity of Syzygium cumini bark. Fitoterapia 72: 369-375.

Oga S 2003. Fundamentos de toxicologia. São Paulo: Atheneu.

Pepato MT, Mori DM, Baviera AM, Harami JB, Vendramini RC, Brunetti IL 2005. Fruit of the jambolan tree (Eugenia jambolana Lam.) and experimental diabetes. J Ethnopharmacol 96: 43-48.

Pio Corrêa M 1974. Dicionário das plantas úteis do Brasile das exóticas cultivadas. Rio de Janeiro: Instituto Brasileiro de Desenvolvimento Florestal.

Ravi K, Sivagnanam K, Subramanian S 2004. Anti-diabetic activity of Eugenia jambolana seed kernels on streptozotocin-induced diabetic rats. J Med Food 7: 187-191.

Schoenfelder T, Warmlin CZ, Manfredini MS, Pavei LL, Réus JV, Tristão TC, Fernandes MS, Costa-Campos L 2010. Hypoglycemic and hypolipidemic effect of leaves from Syzygium cumini (L.) Skeels, Myrtaceae, in diabetic rats. Rev Bras Farmacogn 20: 222-227.

Sharma SB, Nasir A, Prabhu KM, Murthy PS, Dev G 2003. Hypoglycaemic and hypolipidemic effect of ethanolic extract of seeds of Eugenia jambolana in alloxaninduced diabetic rabbits. J Ethnopharmacol 85: 201206.

Slowing K, Carretero E, Villar A 1994a. Anti-inflammatory activity of leaf extracts of Eugenia jambos in rats. $J$ Ethnopharmacol 43: 9-11.

Slowing K, Sollhuber M, Carretero E, Villar A 1994b. Flavonoid glycosides from Eugenia jambos. Phytochemistry 37: 255-258.

Somova LO, Nadar A, Rammanan P, Shode FO 2003. Cardiovascular, antihyperlipidemic and antioxidant effects of oleanolic and ursolic acids in experimental hypertension. Phytomedicine 10: 115-121.

Souza Brito ARM 1994. Manual de ensaios toxicológicos in vivo. Campinas: Unicamp, p. 22.

Sridhar SB, Sheetal UD, Pai MR, Shastri MS 2005. Preclinical evaluation of the antidiabetic effect of Eugenia jambolana seed powder in streptozotocin-diabetic rats. Braz J Med Biol Res 38: 463-468.

Teixeira CC, Fuchs FD, Blotta RM, Knijnik J, Delgado IC, Netto MS, Ferreira E, Costa AP, Müssnich DG, Ranquetat GG 1990. Effect of tea prepared from leaves of Syzygium jambos on glucose tolerance in nondiabetic subjects. Diabetes Care 13: 907-908.

Teixeira CC, Pinto LP, Kessler FH, Knijnik L, Pinto CP, Gastaldo GJ, Fuchs FD 1997. The effect of Syzygium cumini (L.) skeels on post-prandial blood glucose levels in non-diabetic rats and rats with streptozotocin-induced diabetes mellitus. J Ethnopharmacol 56: 209-213.

Teixeira CC, Rava CA, Mallman da Silva P, Melchior R, Argenta R, Anselmi F, Almeida CRC, Fuchs FD 2000. Absence of antihyperglycemic effect of jambolan in experimental and clinical models. J Ethnopharmacol 71: 343-347.

Villasenor IM, Lamadrid MR 2006. Comparative antihyperglycemic potentials of medicinal plants. $J$ Ethnopharmacol 104: 129-131.

\section{*Correspondence}

Selma do N. Silva

Laboratório de Pesquisa e Pós-graduação em Farmacologia, Departamento de Ciências Fisiológicas, Centro de Ciências Biológicas e da Saúde, Universidade Federal do Maranhão Avenida dos Portugueses, s/n, 65085-580 São Luis-MA, Brazil selmansilva@ufma.br

Tel.: +559833018533

Fax: +559833018004 